\title{
Durability Properties on Marine Algae Concrete
}

\author{
R.Ramasubramani, Pennarasi.G,M. B. Sridhar, S.Prakashchandar
}

\begin{abstract}
Investigation of marine algae had its progress, due to chemical reaction with cement as a result nature gets affected by contamination and thus the inclusion of algae in the concrete found to control the destructive reactions. Algae are natural congenial which adds to the monetary of the concrete and, in the meantime, there is a decline of the wastes. Durability of concrete assumes an essential job in concrete structures. Durability of concrete might be characterized as the capacity of cement to withstand weathering activity and acid attack by retaining its ideal building properties. There are different materials utilized in the concrete to increase durability property. In this investigation, marine brown algae was utilized as added substance with concrete. A fixed water to cement ratio $(W / C=0.5)$ for $M 25$ grade concrete was adopted with different marine brown algae percentages at $2 \%, 5 \%$ and $8 \%$. The outcome demonstrates that $8 \%$ marine algae concrete performed well when contrast with traditional concrete. Deflection behaviour test established that thecrucial load limit of ideal mix concrete slab was found to be higher than the customary conventional concrete slab.
\end{abstract}

Key Words: Marine brown algae, Durability properties, sulphate attack, RCPT, acid resistance test.

\section{INTRODUCTION}

\subsection{General.}

Algae use inorganic supplements, for example, nitrogen and phosphorus and are considered to be photosynthetic amphibian plant.Plentiful seaweeds gather enormously to form phaeophyceae or brown algae. There are about 1500 2000 types of marine algae worldwide. The greenish darker shading is because of the presence of fucoxanthin shade in brown algae. Various sizes and shapes of brown algae are available. A trivial, embellished tufts of slender cells which are centimetres long are developed from the tiny individuals of the gathering. A few species in certain phase of their life make the complete alage into a miniature form with just a couple of cells. Bigger size brown algae are developed in different gathering. They are used for various purposes such as fertilizer, energy source, nutrition source, shades, adulteration control, and also in healing purposes. The most widely employed construction substance on the planet is concrete dependent on Portland concrete, and its generation follows a form of growth. In 2011, the world creation of Portland concrete attained $2.8 \times 10^{9}$ tonnes. It is trusted to anaugmentationof around $4 \times 10^{9}$ tonnes in 2050. Synthetic admixtures occupies about $15 \%$ of the all - out concrete creation, mortar or grout at blending which alter their behaviour, either in new or solidified state.

Revised Manuscript Received on December 30, 2019.

* Correspondence Author

R.Ramasubramani, Department of Civil Engineering, Faculty of Engineering and Technology SRM Institute of Science and Technology, Kattankulathur-603 203, Tamil Nadu, India.

Pennarasi. G, M. B. Sridhar, Department of Civil Engineering, Faculty of Engineering and Technology SRM Institute of Science and Technology, Kattankulathur-603 203, Tamil Nadu, India. Engineering and Technology SRM Institute of Science and Technology, Kattankulathur-603 203, Tamil Nadu, India.

(C) The Authors. Published by Blue Eyes Intelligence Engineering and Sciences Publication (BEIESP). This is an open access article under the CC BY-NC-ND license (http://creativecommons.org/licenses/by-nc-nd/4.0/)
S. Prakashchandar, Department of Civil Engineering, Faculty of

\subsection{Need for this study}

The development of construction industry is moving fast as it results more usage of cement which the natural resources are consumed in a high scale.

To control the usage of cement, substitutes are very much needed. The chemical reaction with cement emits carbon -di - oxide which pollutes the environment causes harmful reactions. Algae which is found to be environmental friendly can control the harmful reactions caused due to cement in concrete.

\section{MARINE ALGAE}

Sea encompasses about $71 \%$ of the world. The most momentous herbivores in sea are phytoplankton and benthic algae. The marine algae noticeably known as seaweeds are avarious gathering of photoautotrophic individuals. These are of different forms (filamentous, lace like, or plate like) that contain shades, for example, chlorophyll, carotenoids, and xanthophylls'. The filthyshores give great link focusing in a regularly moving and dynamic circumstances, therefore the evolution of marine algae is plentiful at the sandy shore. The prime sort of flora is a filamentous large scale algae that join waterfront concrete structure. The colonization occurs due to the steadyworn spot of the inferior locales by the influence of wavewhich ultimately stimulates the movement of sand and little stones at the base. Various seaweeds can be found in this statedespite chaetomorpha reception apparatuses, a twosome ofirresistible animal groups. These algae are ordered in the Phylum Chlorophyta. Several types of algae join to form rock and concrete substratesclose to the sea surface. As they are attached to a substrate, they do not have the property toheave up on the shoreline by the waves.

\section{MARINEALGAE CONCRETE}

Seaweed has been utilized in the present investigation to reinforce the concrete mortar that is a rich wellspring of minerals, nutrients and other crucial materials. Literary works demonstrate that algae can be utilized as a concrete substitution item to deliver green bond. So alum sludge was considered as a development material by including it in concrete. The look for financially savvy, ecoaccommodating (green) transfer choices and the likelihood of reusing the sludge have turned into a dire need. Notwithstanding transfer issues, the expanding measures of alum sludge delivered every day are activating significant natural and financial concerns.

\section{EXPERIMENTAL INVESTIGATION}

\subsection{General}

The optimal amount of marine brown algae was found by casting cubes of different dosage of brown algae (5\%, 10\% and $15 \%$ by weight of cement).

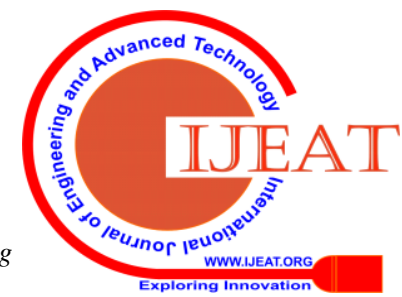




\section{Durability Properties on Marine Algae Concrete}

The casting of cubes and cylinders were done as per mix proportion and tested for 3, 7 and 28 days strength.

\subsection{Rapid Chloride Penetration Test (RCPT)}

Reinforced concrete structures are exposed to critical environmental conditions.

For strengthened concrete scaffolds, a significant type of environmentalattack is chloride ingress, which stimulatesthe corrosion of the steel and a subsequent decrease in the quality, functionality of the structure. This may lead to early fix or prematurereplacement of the structure. A technique for avoiding such decay is to prevent the entry of chlorides by utilizing generally impervious concrete. The capability of chloride particles to infiltrate the concrete should be referred to design and quality control purposes. The entrance of the concrete by chloride, in any case, is a moderate procedure. In this way, so as to survey chloride infiltration, a test strategy that accelerates the procedure is required, to allow the determination of diffusion values in a serviceable time. Rapid chloride entrance test includes acquiring a 100 mm (4 in.) diameter core or cylinder sample from the trial concrete. A $50 \mathrm{~mm}$ (2 in.) example is taken from the sample. The side of the specimen cylindrical in shape is covered with epoxy and it is permitted to dry. It is then placed in the test gadget. The left-hand side $(-)$ of the test cell is loaded up with a $3 \%$ $\mathrm{NaCl}$ arrangement. The right-hand side $(+)$ of the test cell is loaded up with $0.3 \mathrm{~N} \mathrm{NaOH}$ arrangement. The framework is then associated and a 60-volt potential is connected for 6 hours. Readings are taken for every 30 minutes. Toward the finish of 6 hours, the sample is evacuated from the cell and the measure of coulombs went through the sample is determined. A schematical illustration of the test setup has been shown in Figure.1

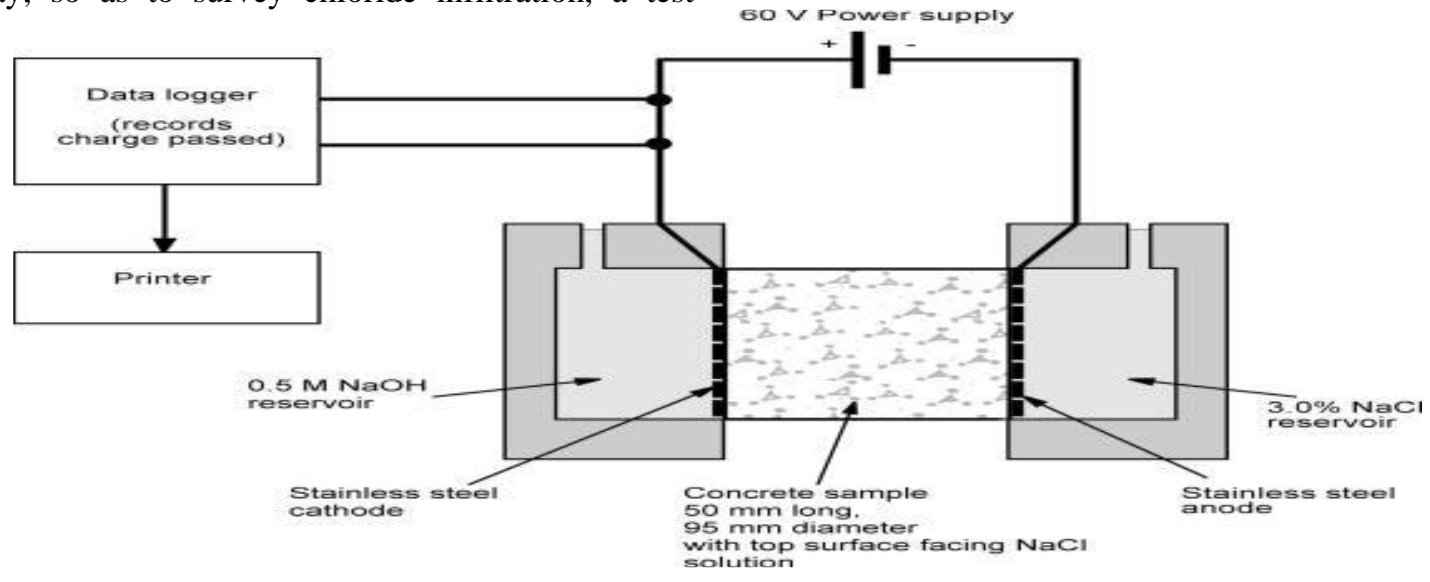

Figure.1 Test setup (as per ASTM C1202)

\subsection{Sulphate Attack Test}

The test is performed to decide the resistance of concrete to Sulphate attack. The test strategy includes setting up the concrete cubes of sizes $150 \times 150 \times 150 \mathrm{~mm}$. Three specimens of traditional concrete and three samples of marine brown algae concrete are readied. It is kept for curing submerged for 28 days. After the restoring time frame, every one of the samples are gaugedand the loads are noted down. The samples are then submerged in 5\% sodium sulphate arrangement and restored for an additional 28 days. At that point the specimens are taken out and the surfaces are cleaned. The loads of the specimens were again taken and rate decline in loads is organized. Next, the specimens are tested for its compressive strengths and the rate decline in strength is noted down. An example of sodium sulphate in the powder structure has been appeared in Figure. 2 demonstrates the sodium sulphate and Figure. 3 indicates concrete specimens kept for relieving inside a drum in sodium sulphate answer for 28 days.

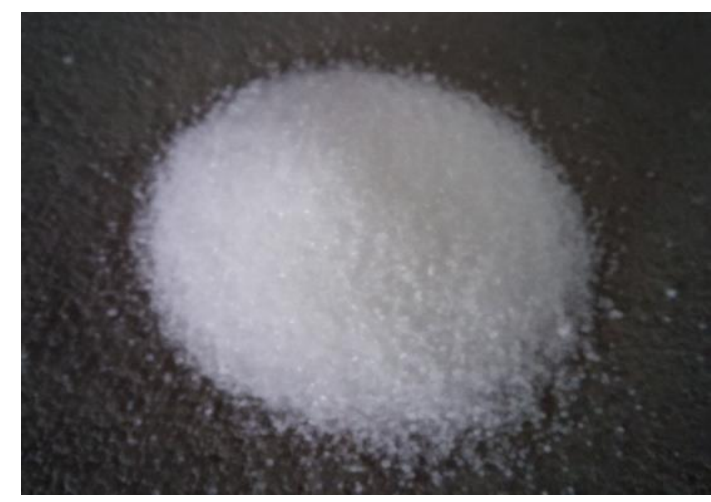

Figure. 2 Sodium Sulphate

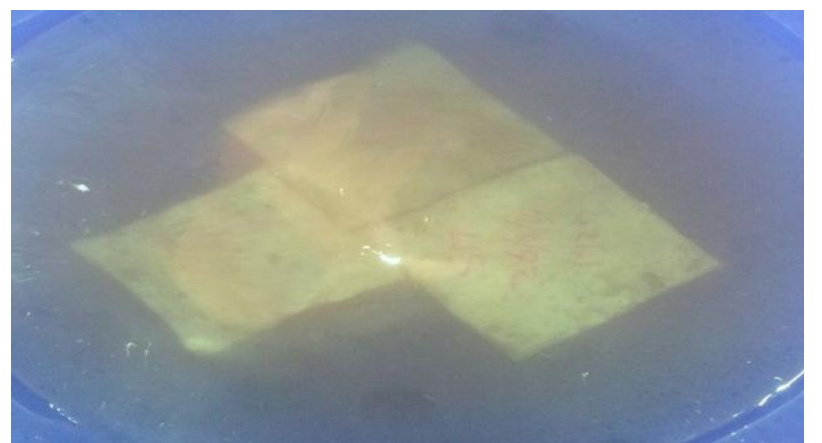

Figure.3 Cubes under curing in Sodium Sulphate solution 


\subsection{Acid Attack Test}

The test is performed to decide the resistance of concrete to corrosive assault test. The test technique includes setting up the concrete cubes of sizes $150 \times 150 \times 150 \mathrm{~mm}$. Three specimens of conventional concrete and three specimens of glass powder concrete are readied. It is kept for curing submerged for 28 days. After the restoring time frame, every one of the specimens are gauged and the loads are noted down. The specimens are then drenched in 5\% concentrated sulphuric corrosive arrangement and cured for an additional 28 days. At that point the specimens are taken out and the surfaces are cleaned. The loads of the specimens are again taken and rate decline in loads is classified. Next, the specimens are tested for its compressive strengths and the rate decline in strength is noted down. The example of a concentrated sulphuric corrosive solution has been appeared in Figure. 4 and Figure. 5 indicates concrete specimens kept for curing inside a concentrated sulphuric corrosive answer for 28 days.

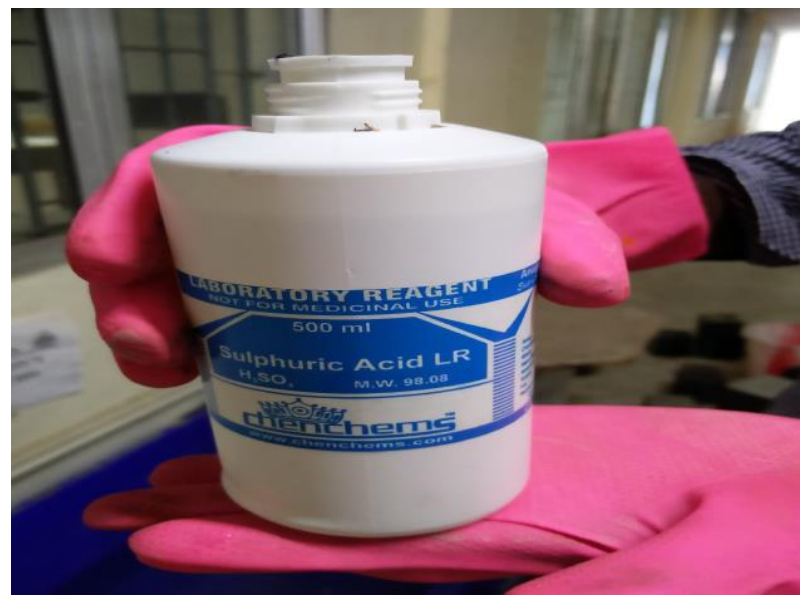

Figure. 4 Concentrated Sulphuric acid

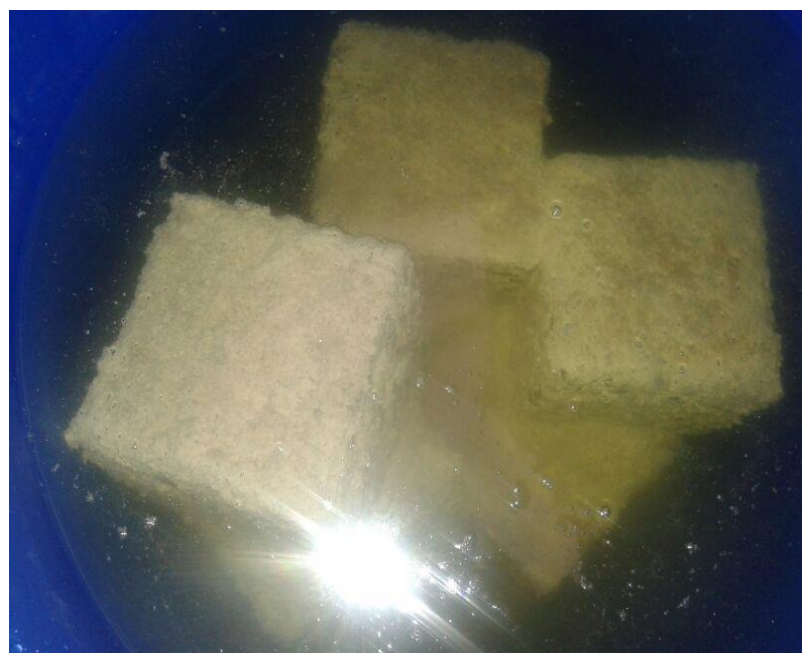

Figure. 5Concrete cubes under curing in $\mathrm{H}_{2} \mathrm{SO} 4$

\subsection{Water permeability test}

An important index for durability of concrete is its degree of permeability. The principle involves in developing water permeability apparatus is exerting a water column under a specified pressure on identified locations for a predetermined period.

\subsection{Fabrication of water permeability apparatus}

For this study, the maintenance department fabricates water permeability apparatus. The cylinder core of dimension $100 \mathrm{~mm}$ diameter and $200 \mathrm{~mm}$ length is kept in the permeameter cell. The permeameter cell has a dimension of $100 \mathrm{~mm}$ diameter and $300 \mathrm{~mm}$ length. The top and bottom of permeameter cell are tightly closed with stoppers and the top and bottom stopper are clamped together by means of a steel clamp to arrest the leakage of water . PVC pipe of $100 \mathrm{~mm}$ diameter is used as permeameter cell. To maintain the pressure head, a glass tube of $2.5 \mathrm{~cm}$ diameter and the $1.2 \mathrm{~m}$ lengths is used which is inserted in the centre of the rubber stopper. To arrest the side leakage in between permeameter cell and cylinder specimen, $\mathrm{M}$-seal is applied all around the specimen. A constant head of $2 \mathrm{~m}$ is maintained throughout the test.

\subsection{Test procedure}

The test specimen is of $100 \mathrm{~mm}$ diameter and $200 \mathrm{~mm}$ length is taken and securely sealed in the permeameter cell and connected to a manometer tube. The test is to be carried out by injecting water into the glass tube and reservoir of the permeameter cell. The amount of water flowing into the specimen is to be monitored. The test is to be continued for 3 hours during which the flow of water is recorded at 15 minutes interval. The following equation is used for calculating water permeability.K $=(\mathrm{Q} \times \mathrm{L}) /(\mathrm{A} \times \mathrm{T} \times \mathrm{H})$ ... Equation...(1)

\subsection{Deflection test for slab}

The slabs of the dimension $850 \times 300 \times 100 \mathrm{~mm}$ were casted for both conventional and marine brown algae concrete. The concrete grade in both the cases is M25.

\subsection{Conduct of experiments}

The slab to be tested was lifted and kept inside the stacking stage of the casing. Water powered jack of $25 \mathrm{~T}$ limits was set over the steel ball for use of load. $20 \mathrm{~T}$ limit demonstrating ring was set over the water driven jack at its middle. One linear variable displacement transducer (LVDT) is set at the focal point of the slab at the base, the section was adjusted to the point that the centres of the demonstrating ring and piece are in a similar line by utilizing plumb bob. The loading on slab is done starting at one point loading essentially simply supported slab. Presently the arrangement has been made prepared for carrying out the examination and the LVDT were likewise set for zero preceding the beginning of tests. The heap was always connected through the water powered jack. A steel ball has exchanged the heap to its edges similarly. Slab was permitted and exposed to a consistent increment in the rate of loading till a ultimate load was reached

\subsection{Specimen preparation}

Formwork utilizing plywood was set up for the slab size. No reinforcements are given. The internal surfaces of the form were covered with a flimsy film of unrefined petroleum to avoid grip of cement with the shape before pouring the solid. Every one of the elements of the blend were gauged and hand blended by the design mix separately. The concrete was set in three layers compacted utilizing a needle vibrator. 


\section{Durability Properties on Marine Algae Concrete}

Care should be given for uniform compaction. After $24 \mathrm{~h}$, the formwork were expelled and put in the curing tank for 28 days. Before testing, slabs were whitewashed to encourage the perceptions of cracking patterns amid the tests.

\subsection{Instrumentation for testing}

The testing was prepared in a loading frame of captivity 40 tons. . Load was applied by means of a hydraulic jack of capability 25 tonnes. The pile was assessed with the help of a showing ring of 20 tones cut-off. Redirection of the pole was measured by using LVDT fixed at the midpoint of the slab.

\section{DURABILITY TESTS}

\subsection{Rapid Chloride Penetration Test (RCPT)}

Figure. 6show the laboratory setup of the RCPT test. Table 2displays the values of the current passing in the specimen. The values are obtained by using the equation 1 . It shows that current passing through specimen is moderate when it compare as per ASTM C1202. The amount of chloride passing through the marine algae concrete specimen is when it compares to the conventional concrete.

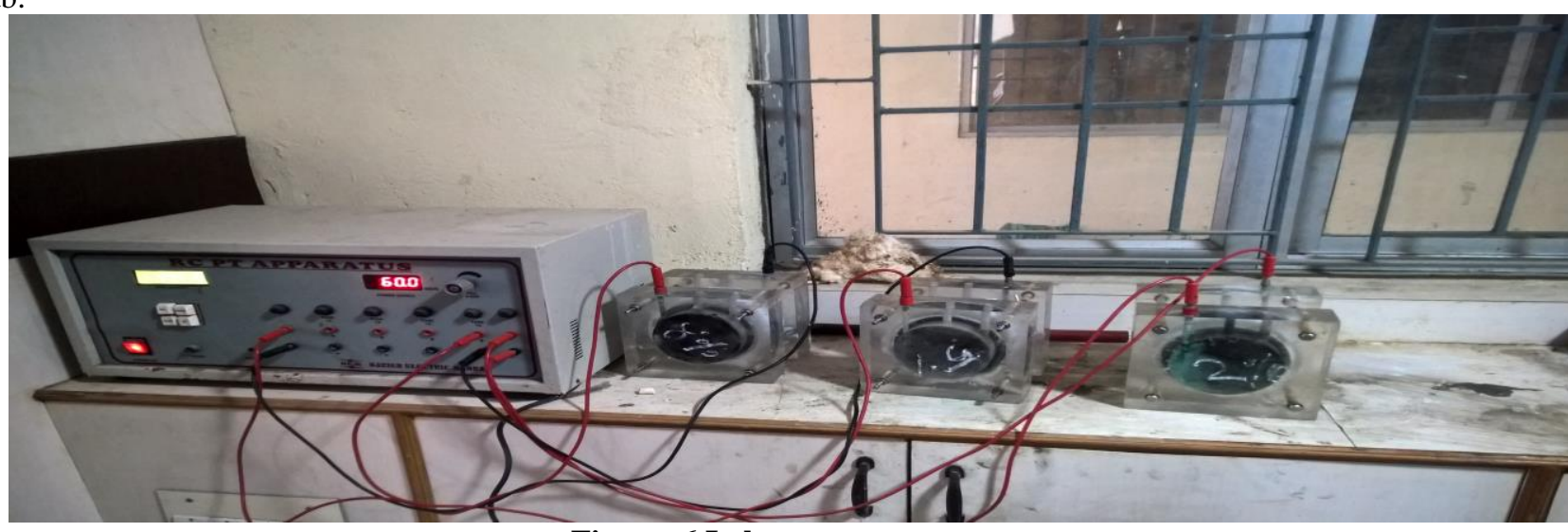

Figure. 6 Laboratory test setup

Table 2 Amount of current passing through concrete

\begin{tabular}{|c|c|}
\hline Mix & Current Passing (columbs) \\
\hline Conventional Concrete (M1) & 3935 \\
\hline 2\% Marine Algae Concrete (M2) & 3682 \\
\hline 5\% Marine Algae Concrete (M3) & 3219 \\
\hline 8\% Marine Algae Concrete (M4) & 3057 \\
\hline
\end{tabular}

\subsection{Sulphate Attack Test}

After 3, 7, 28 days concrete cube is taken out from the solution and allow to dry. Then the concrete cube is tested in compression testing machine. Table 3 demonstrates the decrease of weight in concrete specimens held under curing in Sodium Sulphate arrangement. Table 4 demonstrates the decrease of compressive strength of concrete specimens held under curing in Sodium Sulphate arrangement.Figure.7 shows the comparative chart on compressive strength of conventional concrete and marine algae concrete

Table 3 Change in weight of concrete

\begin{tabular}{|c|c|c|c|c|}
\hline Type of concrete & Days & Initial weight (kg) & $\begin{array}{c}\text { Weight taken after } \\
\text { curing (kg) }\end{array}$ & $\begin{array}{c}\text { Reduction in weight } \\
\text { (\%) }\end{array}$ \\
\hline \multirow{3}{*}{ Conventional concrete } & & & 8.78 & 0.57 \\
\cline { 2 - 5 } & 3 & 8.83 & 8.65 & 1.58 \\
\cline { 2 - 5 } & 28 & 8.79 & 8.62 & 2.15 \\
\hline \multirow{3}{*}{ 2\% Marine Algae Concrete (M2) } & 3 & 8.77 & 8.72 & 0.54 \\
\cline { 2 - 5 } & 7 & 8.85 & 8.71 & 1.57 \\
\hline \multirow{3}{*}{$5 \%$ Marine Algae Concrete (M3) } & 28 & 8.79 & 8.61 & 2.09 \\
\cline { 2 - 5 } & 3 & 8.78 & 8.74 & 0.51 \\
\cline { 2 - 5 } & 28 & 8.75 & 8.61 & 1.55 \\
\hline \multirow{2}{*}{$8 \%$ Marine Algae Concrete (M4) } & 3 & 8.89 & 8.71 & 1.97 \\
\cline { 2 - 5 } & 7 & 8.74 & 8.68 & 0.49 \\
\cline { 2 - 5 } & 28 & 8.81 & 8.67 & 1.53 \\
\hline
\end{tabular}


Table 4 Change in compressive strength of concrete

\begin{tabular}{|c|c|c|c|}
\hline \multirow{2}{*}{ Mix } & \multicolumn{3}{|c|}{ Compressive strength in (N/. mm $\left.{ }^{2}\right)$} \\
\cline { 2 - 4 } & \multirow{3}{*}{ days } & $\mathbf{7}$ days & $\mathbf{2 8}$ days \\
\hline Conventional concrete (M1) & 24.6 & 24.1 & 23.8 \\
\hline 2\% Marine Algae Concrete (M2) & 24.9 & 24.5 & 24.3 \\
\hline 5\% Marine Algae Concrete (M3) & 24.7 & 24.3 & 24.2 \\
\hline 8\% Marine Algae Concrete (M4) & 24.8 & 24.4 & 24.2 \\
\hline
\end{tabular}

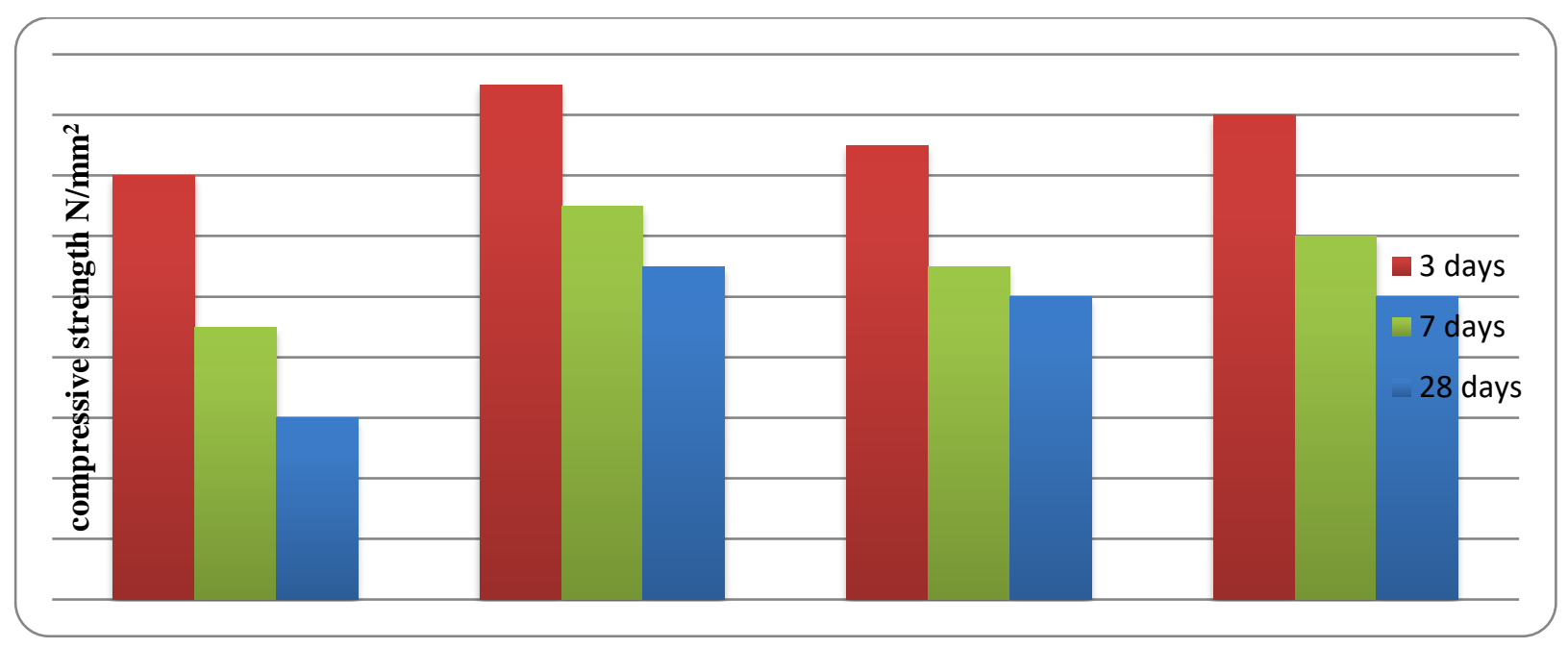

Figure. 7A Comparative chart on compressive strength of conventional concrete and marine algae concrete

Hence, it is concluded that percentage of weight reduction and then for the marine algae concrete is less when compare to the conventional concrete and the compressive strength of marine algae concrete is more when compared to the conventional concrete.

\subsection{Acid Attack Test}

After 3, 7 and 28 days concrete cubesare allowed to dry. Then the concrete cube is tested in compression testing machine. Figure. 8shows theExamination of compressive strength of regular concrete and marine algae concrete Table 5 demonstrates the decrease of weight in concrete specimens held under curing in concentrated Sulphuric corrosive arrangement. Table 6 demonstrates the decrease of compressive strength of concrete specimens held under curing in concentrated Sulphuric corrosive arrangement.

Table 5 Change in weight of concrete

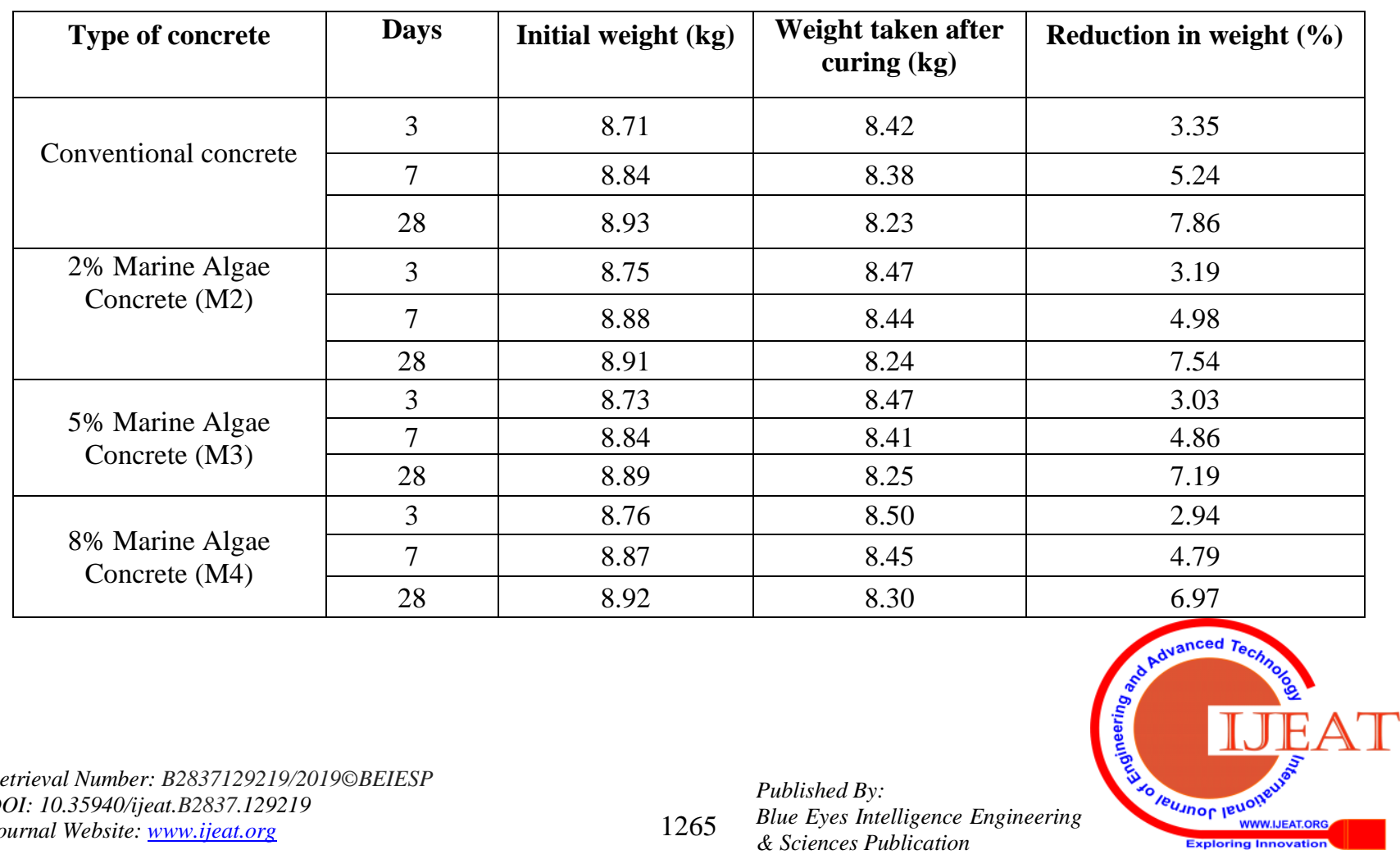


Durability Properties on Marine Algae Concrete

Table 6 Change in compressive strength of concrete

\begin{tabular}{|c|c|c|c|}
\hline \multirow{2}{*}{ Mix } & \multicolumn{3}{|c|}{ Compressive strength in (N/ $\mathbf{m m}^{\mathbf{2}}$ ) } \\
\cline { 2 - 4 } & $\mathbf{3 ~ d a y s}$ & $\mathbf{7}$ days & $\mathbf{2 8}$ days \\
\hline Conventional concrete (M1) & 25.3 & 24.7 & 24.2 \\
\hline 2\% Marine Algae Concrete (M2) & 25.6 & 24.9 & 24.5 \\
\hline 5\% Marine Algae Concrete (M3) & 25.8 & 25.2 & 24.6 \\
\hline 8\% Marine Algae Concrete (M4) & 26.1 & 25.5 & 24.3 \\
\hline
\end{tabular}

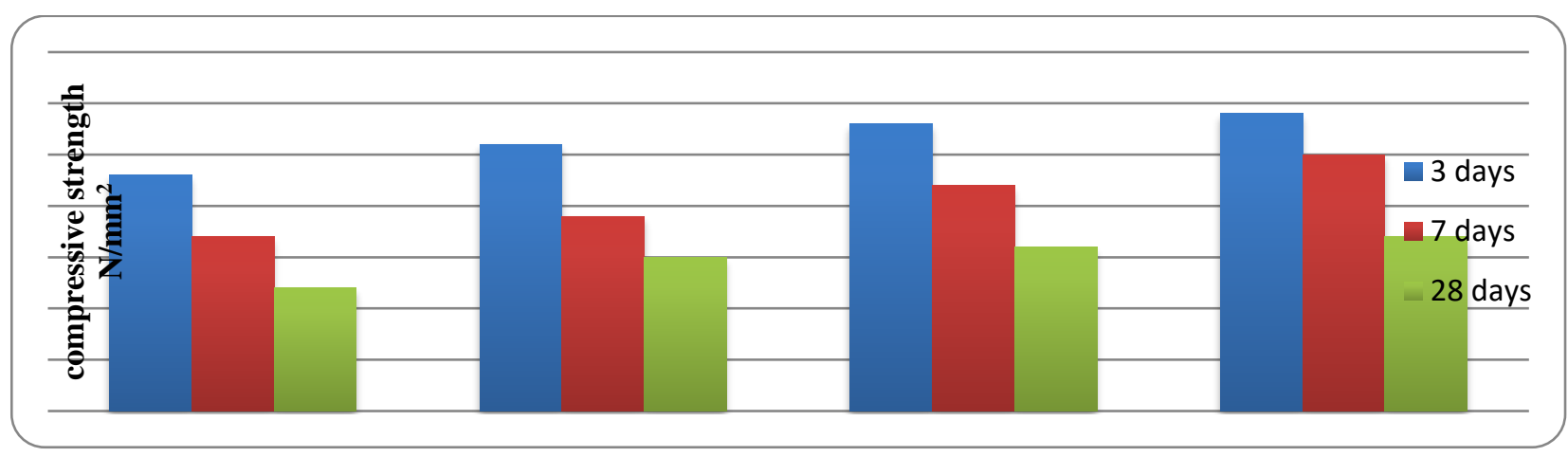

Figure. 8A Comparative chart on compressive strength of conventional concrete and marine algae concret Hence, it is concluded that percentage of weight reduction and the for the marine algae concrete is less when to contrast with the ordinary cement and the compressive strength of marine algae concrete is more in difference with the

The result shown in Table 7 is calculated by using the equation 1 . The result shows that amount of water entering in the marine algae concrete is less when to compare to the conventional concrete. consistent cement.

\subsection{Water Permeability Test}

Table 7Values of Coefficient of Permeability

\begin{tabular}{|c|c|}
\hline Mix & Coefficient of permeability $\mathbf{~}$ in $\mathbf{~ m} / \mathbf{s e c}$ \\
\hline Conventional concrete & $1.05 \times 10^{-7}$ \\
\hline 2\% Algae concrete & $3.18 \times 10^{-8}$ \\
\hline 5\% Algae concrete & $3.84 \times 10^{-8}$ \\
\hline 8\% Algae concrete & $4.67 \times 10^{-8}$ \\
\hline
\end{tabular}

\subsection{Deflection characteristics of slab}

The diversion of the slab is considered on accordance with the formation of cracks with separate to the heap connected and the deflection of the section at the midpoint. Figure. 9 demonstrates trial setup of the slab. The greatest redirection of the customary cement is $6.02 \mathrm{~mm}$ at 3.6

tonnes of load and beginning split creates at 2.0 tons and for ideal mixture the most extreme avoidance is $5.22 \mathrm{~mm}$ at 4.4 tonnes of load and initial crack creates at 2.6 tons. Figure. 10 demonstrates the section subsequent to stacking. Figure. 11 demonstrates the heap versus deflection diagram for ordinary concrete and ideal mixture concrete.

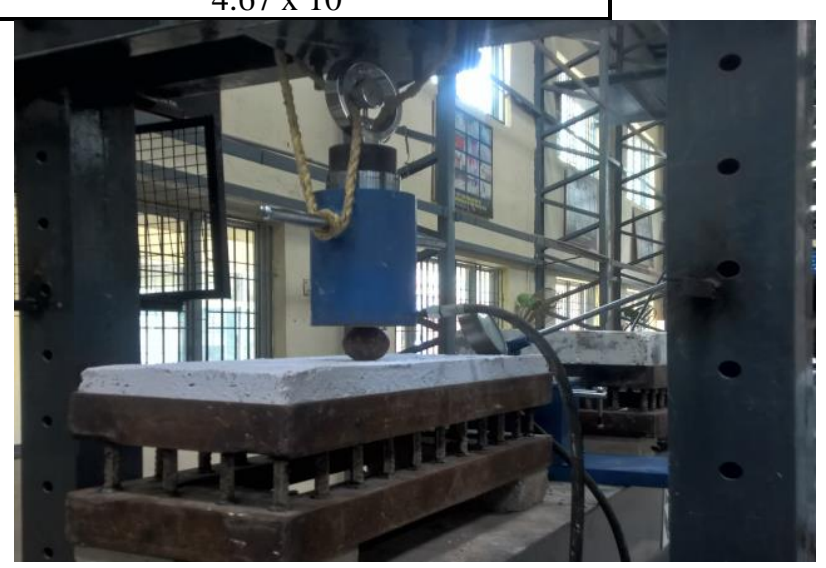




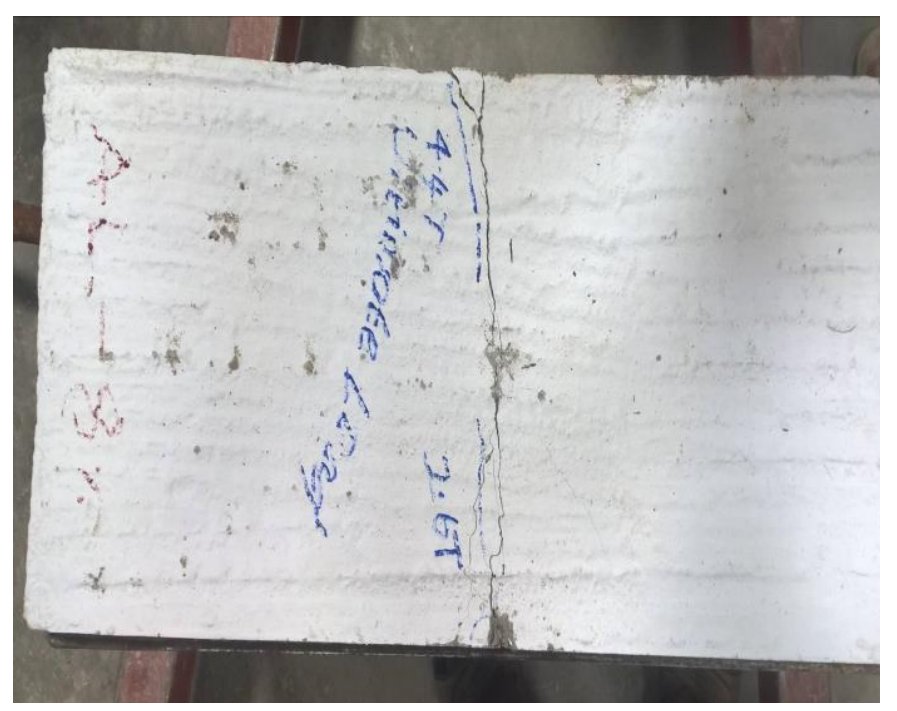

Figure. 9 Experimental Setup Figure. 10 Slab After Loading

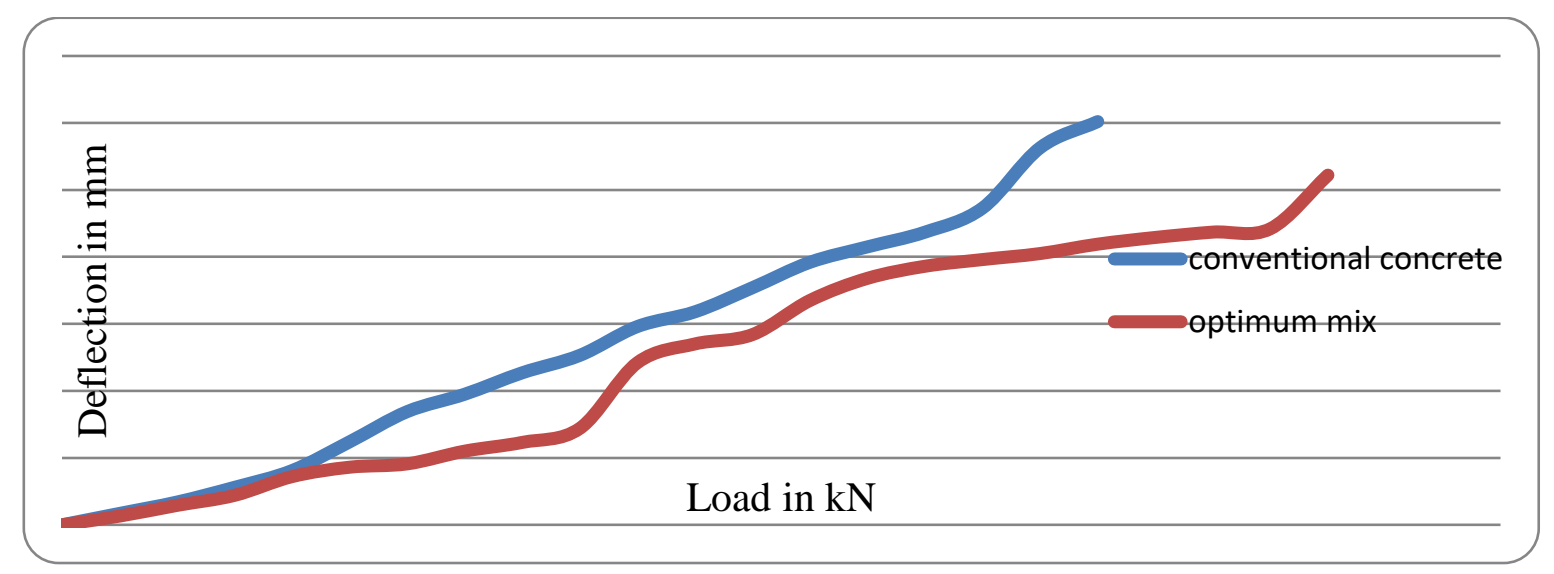

Figure. 11 Load vs Deflection graph for CC and OP

Hence, it is concluded that optimum mix concrete has taken more load and less deflection when it is compared to the conventional concrete.

\section{CONCLUSIONS}

Rapid Chloride Penetration test was conducted to study the penetration of chloride ion. With the results of the experiment the chloride ion permeability was found to be moderate. Corrosive attack and alkalinity attack directed on the concrete demonstrated a lessening in weight and compressive strength. The sum decrease of the weight and compressive strength is high when contrasted with traditional cement for both corrosive and Sulphate test .The water permeability shows the amount of penetration of water to the specimen is less for marine algae concrete in comparison with conventional concrete. The deflection of the slab is improved comparatively for marine algae concrete slab to the conventional concrete slab.

\section{ACKNOWLEDGEMENT}

The creators wish to thank the SRM IST Management, for their help to finish this investigation and the individuals who legitimately or in a roundabout way associated with this examination.

\section{REFERENCES}

1. R.Ramasubramani, K.S. Sathyanarayanan,et al., Rasayan Journal of Chemistry, 9(4),706(2016)

2. S. PrakashChandar, K. Gunasekaran, N.SaiSandeep, S.Manikandaprabhu, Rasayan Journal of Chemistry,10(2), 528(2017),

3. R. Ramasubramani, Shakthivel V, Manikandaprabhu.S, GanapathyRamasamy, $N$.The Influence of Marine algae on the mechanical properties of concrete, InternationalJournal of Innovative technology and Exploring engineering (2019): Vol 8, No 11, pp $536-$ 543.

4. Dransfield J. Admixtures for concrete mortar and grout. In: Newman J, Choo BS, editors. Advanced concrete technology, constituent materials. Oxford: Butterworth-Heinemann; (2003).

5. F.M. Leon-Martinez 'Study of nopal mucilage and marine brown algae extract as viscosity-enhancing admixtures for cement based materials'. P.F. de J. Cano-Barrita (2014); Vol. 65, No. 9, pp. 1-11

6. Large-particulated fluids: analysis of the ball measuring system and comparison to debris flow rheometry. RheolActa (2009); Vol. 48, No. 8, pp. 715-33.

7. Lachemi M, Hossain KMA, Lambros V, Nkinamubanzi P-C, Bouzoubaâ N. Self consolidating concrete incorporating new viscosity modifying admixtures. CemConcr Res 2004;vol. 34, No. (6), pp. 917-26.

8. Malhotra, V.M "No -fines concrete its properties and applications", (1976), journal of American Concrete Institute, title no Vol. 73-54, pp. 628-644.

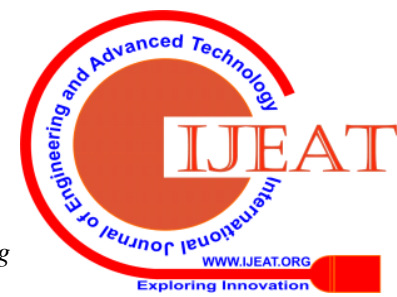




\section{Durability Properties on Marine Algae Concrete}

9. Plank J. 'Applications of biopolymers and other biotechnological products in building materials'. ApplMicrobiolBiotechno (2004); Vol. 66, No. 1, pp.1-9.

10. IS: 383 (1970), Indian standard for specification for coarse aggregates and fine aggregates from natural sources for concrete (second revision), reaffirmed February.

11. IS: 2386 (Part 1) (1963), Indian Standard for methods of test for aggregates for concrete (Part 1) particle size and shape.

12. IS: 12269 (1987), Indian standard for specification for 53 grade OPC, reaffirmed January 1999.

13. IS: 10262 - 1982: Recommended guidelines for concrete mix design, Indian standard institution, New Delhi.

\section{AUTHORS PROFILE}

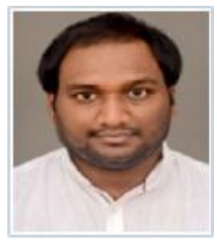

R. Ramasubramaniis currently Assistant Professor in Civil Engineering Department(Structuralengineering specialization) at SRM Institute of Science and Technology, Chennai, India.

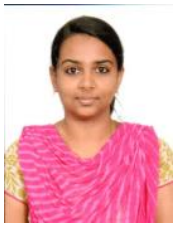

Pennarasi G is currently doing M-Tech Structural Engineering at SRM Institute of Science and Technology, Chennai, India.

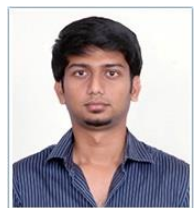

M.B.Sridhar is currently Assistant Professor in Civil Engineering Department (construction engineering and management) at SRM Institute of Science and Technology, Chennai, India.

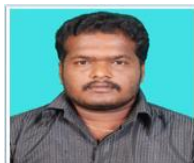

S.Prakashchandar is currently Assistant Professor in Civil Engineering Department (Area: Concrete technology) at SRM Institute of Science and Technology, Chennai, India. 